Arkivoc

Free to Authors and Readers
A Platinum Open Access Journal for Organic Chemistry
Review

Arkivoc 2021, part ix, 130-149

\title{
Recent syntheses of steroid derivatives using the CuAAC "click" reaction
}

\author{
Malika Ibrahim-Ouali, ${ }^{* a}$ and Frédéric Dumurb \\ ${ }^{a}$ Aix Marseille Univ, CNRS, Centrale Marseille, iSm2, F-13397 Marseille, France \\ ${ }^{b}$ Aix Marseille Univ, CNRS, ICR, UMR 7273, F-13397 Marseille, France \\ Email: malika.ibrahim@univ-amu.fr
}

Received 04-26-2021

Accepted 06-21-2021

Published on line $07-28-2021$

\section{Abstract}

The introduction of heterocycles into steroids is often at the origin of a modification of their physiological activity and thus allows the formation of new biologically interesting molecules. Recent advances in the field of steroid synthesis using the copper-catalyzed azide-alkyne cycloaddition (CuAAC) are presented here. Compounds exhibiting known biological activities are also reported in this review. This approach holds great promise and allows us to consider preparing new, highly functionalized complex molecules using the CuAAC "click" reaction.
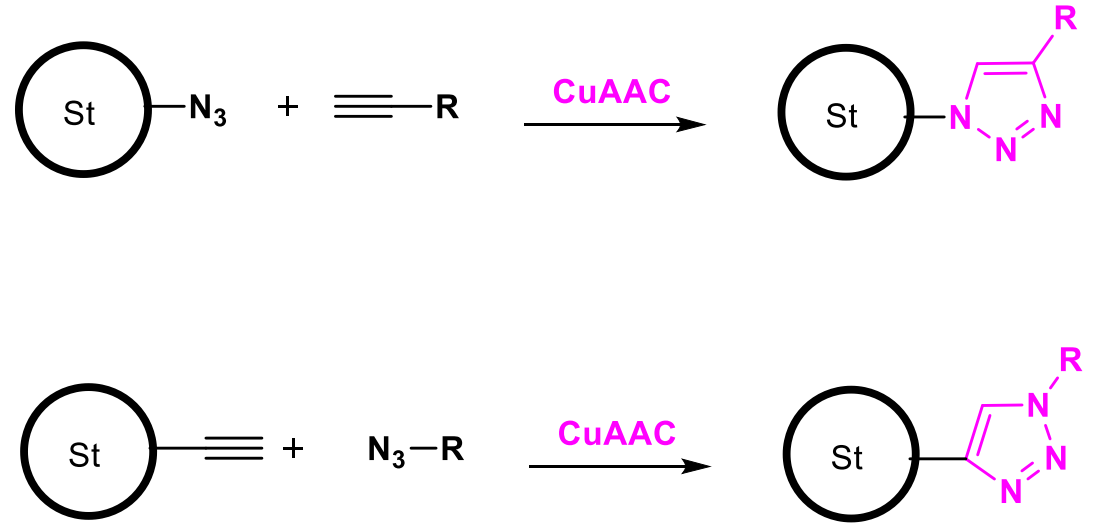

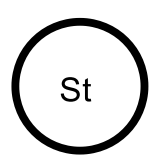

$=$

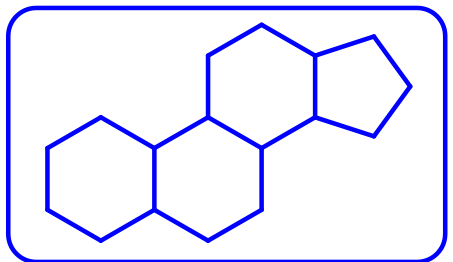

Keywords: click reaction; 1,2,3-triazoles; Cu(I)-catalyzed; azidosteroids 


\section{Table of Contents}

1. Introduction

2. Synthesis of Steroids Using the CuAAC "Click" Reaction

3. Conclusions

4. Acknowlegments

5. References

\section{Introduction}

Steroids form a large and important class of biologically active polycyclic compounds that are widely used in therapeutic chemistry. ${ }^{1-3}$ Even today, the synthesis of the steroid skeleton by increasingly sophisticated strategies continues to hold the attention of chemists. The steroids present in nature and known for their biological importance have been the subject of numerous syntheses and research on these molecules has not ceased to this day. ${ }^{4,5}$

The $[1,2,3]$-triazoles constitute an important family of nitrogenous five-membered heterocycles. They exhibit considerable biological activities, such as antitumor, ${ }^{6}$ anti-HIV, ${ }^{7}$ anti-tuberculosis, ${ }^{8}$ and antibacterial $^{9}$ and also exhibit inhibitory activities of serine hydrolase, ${ }^{10}$ tyronase, ${ }^{11}$ and glycosidase ${ }^{12}$. This azaheterocycle is an interesting connection motif because it is stable to metabolic degradation but above all, it can form hydrogen bonds. This consideration makes it a prime motif for improving the solubility and binding of biomolecular targets. ${ }^{13,14}$ The 1,2,3-triazole moiety cannot be found in nature, yet molecules with 1,2,3triazole units possess various biological activities. The role of these compounds in medicinal chemistry is considerable. In fact, the low basicity of this azaheterocycle makes it non-protonatable in a physiological medium, unlike other azaheterocycles.

In addition, to introduce heterocycles in steroids ${ }^{15-20}$ by modifying the steroid side chain or by substituting the steroid backbone can lead to molecules exhibiting new biological activities. ${ }^{21-25}$ The reviews about this type of steroid are numerous. ${ }^{26}$ They all show that these molecules have a biological potential because they cause distinct cytotoxicity against cancer cell lines. ${ }^{27-30}$

This review presents the latest syntheses of steroid derivatives using the copper-catalyzed azide-alkyne cycloaddition reaction (CUAAC) and possibly the biological activities, from the years 2016-2021. To the best of our knowledge and much to our surprise, there have been no reviews on this subject since $2016 .^{31}$

\section{Synthesis of Steroids Using the CuAAC "Click" Reaction}

In 2016, Kovács et al. ${ }^{32}$ reported the synthesis of 2'-deoxynucleoside conjugates of $13 \alpha$-estrone by applying the copper-catalyzed alkyne-azide click reaction (CuAAC).

They chose the 5'-position of the nucleosides to introduce the azido group and a propargyl ether functional group on the 3-hydroxy group of $13 \beta$-estrone. They obtained the best yields by protecting with acetyl groups the 3'-hydroxy groups of the nucleosides and by changing the 5'-hydroxy groups using the tosyl-azide exchange method. The key step of click reaction between the protected-5'-azidonucleosides and the steroid alkyne was done using 1.5 equivalent of $\mathrm{Cu}(\mathrm{I})$ catalyst (Scheme 1 ). 
Biological evaluation of all conjugates synthesized was realized in vitro through MTT assays for antiproliferative activity against a panel of human adherent cell lines (HeLa, MCF-7, and A2780). They also studied the potential inhibitory activity of the new products on human $17 \beta$-hydroxysteroid dehydrogenase 1 (17?-HSD1) via in vitro radiosubstrate incubation. The most potent with an $\mathrm{IC}_{50}$ value of $9 \mu \mathrm{M}$ was the protected cytidine conjugate and the thymidine conjugate presented a considerable $17 \mu$-HSD 1 inhibitory activity $\left(\mathrm{IC}_{50}=19 \mu \mathrm{M}\right)$.

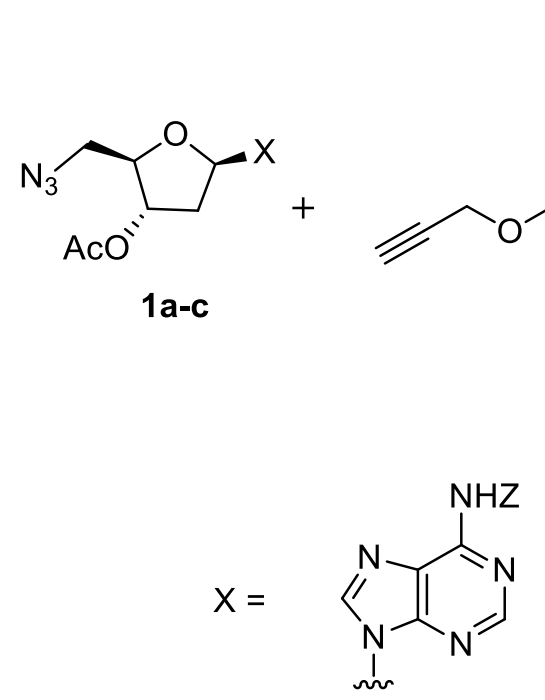

3a $Z=B z, R=A c$

4a $\mathrm{Z}=\mathrm{R}=\mathrm{H}$<smiles>Cc1cn(C)c(=O)[nH]c1=O</smiles>

3b $\mathrm{R}=\mathrm{Ac}$

4b $\mathrm{R}=\mathrm{H}$

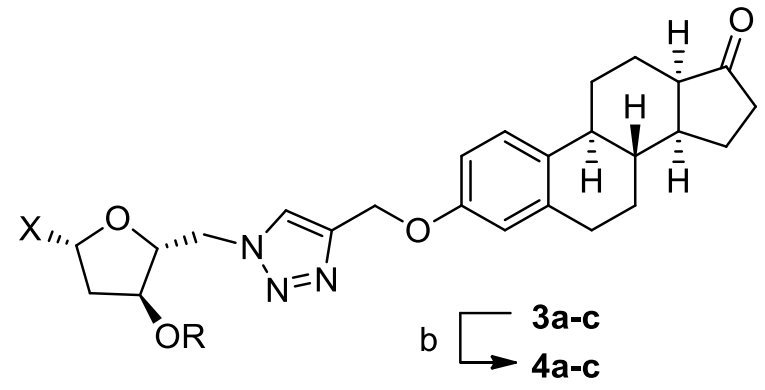<smiles>[Z2]Nc1ccn(C)c(=O)n1</smiles>

3c $Z=B z, R=A c$

4c $\mathrm{Z}=\mathrm{R}=\mathrm{H}$

Reagents : a- Cul, DIPEA, toluene or THF, 61-76\%; b- $\mathrm{NH}_{3}, \mathrm{MeOH}, 81-89 \%$

Scheme 1. CuAAC conjugation reaction of 3'-O-acetyl-5'-azido-2', 5'-dideoxynucleosides and 3-O-propargyl$13 \alpha$-estrone.

Van Liera et al. ${ }^{33}$ described the synthesis of estrogen, testosterone- and 19-nortestosterone conjugates linked to BODIPY (4,4-difluoro-4-bora-3 $\alpha, 4 \alpha$-diaza-s-indacene) or aza-BODIPY to obtain receptor-based fluorescence ligands for imaging breast and prostate cancer. Their synthesis is based on coupling of iodo derivatives of differently substituted BODIPY and aza-BODIPY analogs and steroid alkynes using the click reaction conditions. Their observations in living cells and tissues is possible since their UV-Vis absorption spectral range from 500 to $710 \mathrm{~nm}$ with fluorescence emission properties ranging from 520 to $700 \mathrm{~nm}$.

This method allows to obtain libraries of new products with potential diversified bioactivity by changing functional groups, linker chain length and type, and sequence orientation of a subunit within an E2-BODIPY conjugate. Thus, two covalently coupled conjugates 7 and 9 were synthesized in good yields from azidoBODIPY 6 and steroid alkynes 5 and $\mathbf{8}$ (Scheme 2).

In 2017, Yuan et al. ${ }^{34}$ described the preparation of new derivatives of the $\beta$-sitosterol scaffolds containing 1,2,3-triazole by the reaction of $\beta$-sitosterol with aromatic alkynes via copper(I)-catalyzed azide-alkyne cycloaddition reactions under microwave irradiation. 


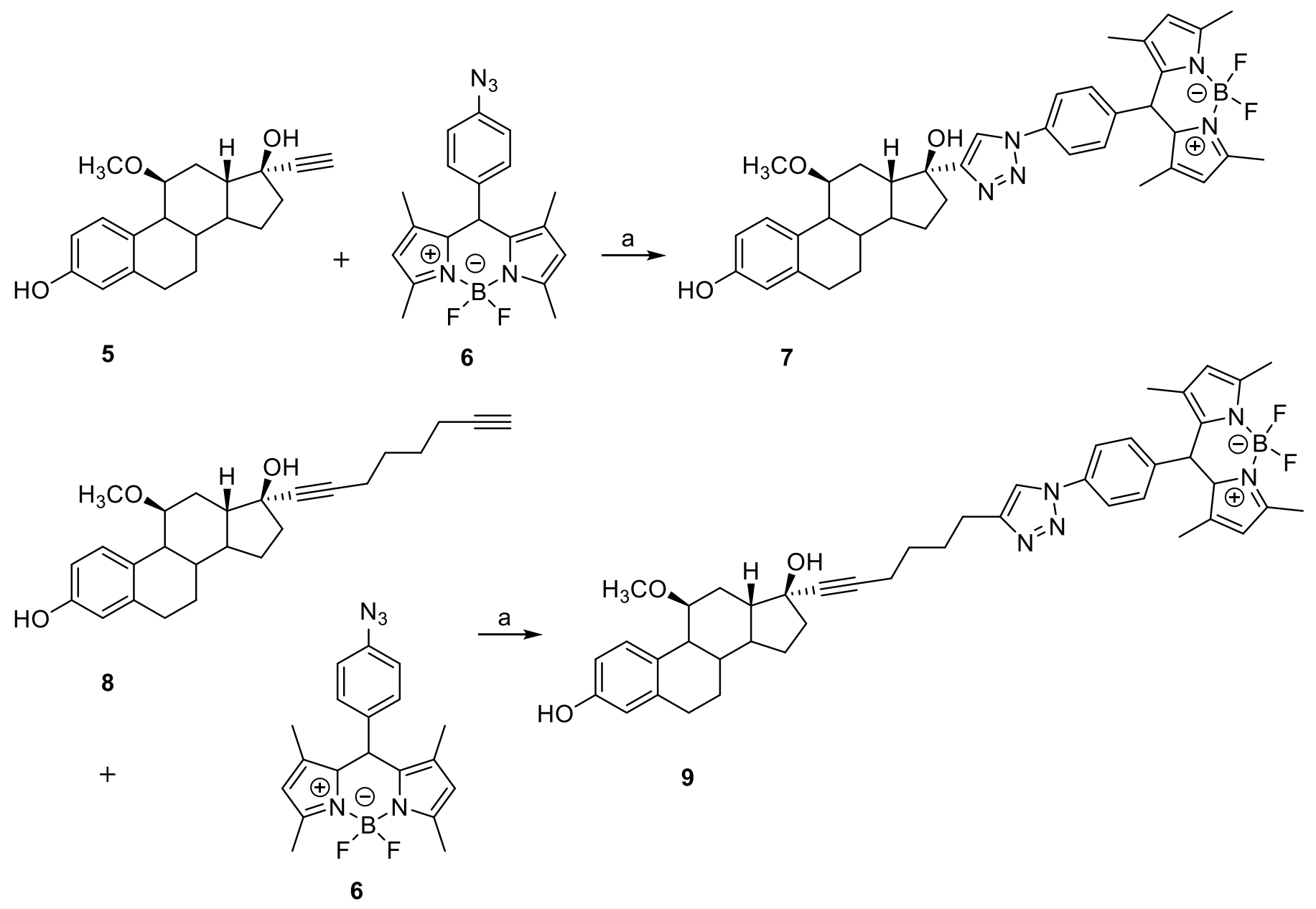

Reagents : a- THF, tBuOH, $\mathrm{H}_{2} \mathrm{O}, \mathrm{CuSO}_{4}$, TBTA, Na-ascorbate

Scheme 2. Synthetic route to prepare 17a-ethynylestradiol-aza-BODIPY conjugates.

The reaction conditions are mild: $\mathrm{H}_{2} \mathrm{O}$ is used as a green solvent and copper as a catalyst. asitosterol-3-yl methanesulfonate $\mathbf{1 1}$ was prepared in good yield by reaction of $\beta$-sitosterol $\mathbf{1 0}$ with methanesulfonyl chloride in $\mathrm{CH}_{2} \mathrm{Cl}_{2}$ using triethylamine as a base, and dimethylaminopyridine (DMAP) as a catalyst. The reaction of the mesylate derivative $\mathbf{1 1}$ with sodium azide in dimethylformamide (DMF) led to $\beta$-sitosterol-3-yl azide $\mathbf{1 2}$ in $83 \%$ yield (Scheme 3).

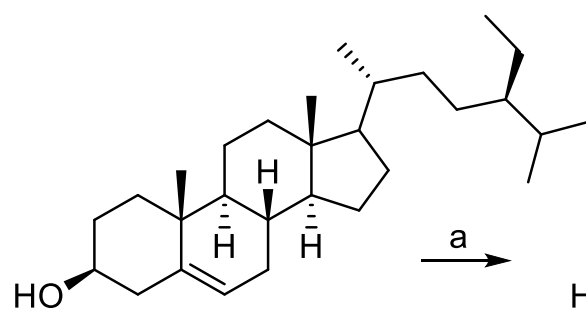

$10 \beta$-sitosterol

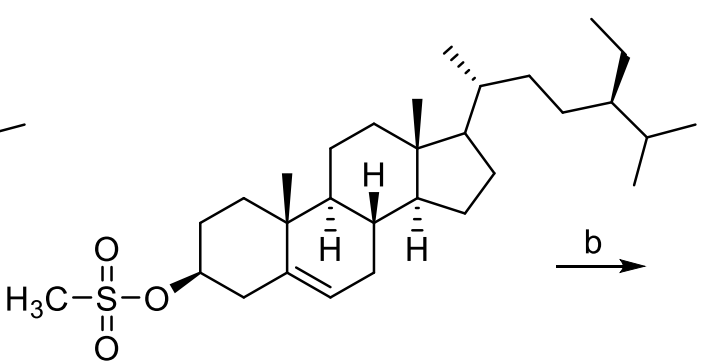

11

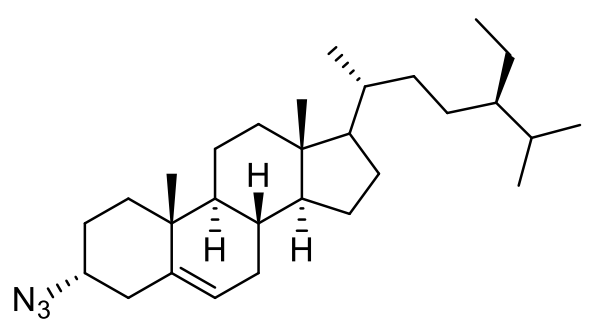

12

Reagents : a- $\mathrm{CH}_{3} \mathrm{SO}_{2} \mathrm{Cl}$, DMAP, $\mathrm{NEt}_{3}, \mathrm{CH}_{2} \mathrm{Cl}_{2}, 0^{\circ} \mathrm{C}, 24 \mathrm{~h}, 76 \%$; b- $\mathrm{NaN}_{3}, \mathrm{DMF}, 90^{\circ} \mathrm{C}, \mathrm{N}_{2}, 24 \mathrm{~h}, 83 \%$.

Scheme 3. Synthesis of $\beta$-sitosterol-3-yl azide 12. 
The use of 10 mol\% of $\mathrm{CuSO}_{4} \cdot 5 \mathrm{H}_{2} \mathrm{O}$ and 20 mol\% of sodium ascorbate as the catalyst, $\mathrm{H}_{2} \mathrm{O}$ as a green solvent at $40{ }^{\circ} \mathrm{C}$ for $30 \mathrm{~min}$ are the best reaction conditions for the copper-catalyzed azide-alkyne cycloaddition (CuAAC).

$\beta$-sitosterol-3-yl azide 12 reacted with a variety of functionalized aromatic alkynes $\mathbf{1 3}$ as presented in Scheme 4.

It is worth pointing out that short reaction times $(0.5 \mathrm{~h})$ and excellent yields (85-95\%) were obtained for the expected $\beta$-sitosterol derivatives $\mathbf{1 4}$ when aromatic alkynes with functional groups at different positions of the aromatic ring (alkyl, $\mathrm{F}, \mathrm{Br}$, and $\mathrm{OCH}_{3}$ ) were used. The same result was observed with heterocyclic or aliphatic alkynes. Furthermore, yields of the products were very good with alkyne possessing a strong electron-withdrawing group. In all cases, three isomers of the desired product were isolated and could be separated by column chromatography. However, in some cases the mixture of isomers was inseparable or when the yield of the corresponding isomer 14" was low, only two isomers or only one were isolated.

In general, $\beta$-sitosterol derivatives 14 were prepared in good yield showing the broad scope of this methodology.

In the same year, Zhang et al. ${ }^{35}$ described the preparation of a novel and simple deoxycholic acid-based fluorescent probe for solvent-dependent multi detection of $\mathrm{Cu}^{2+}, \mathrm{C}_{2} \mathrm{O}_{4}{ }^{2-}$ and $\mathrm{P}_{2} \mathrm{O}_{7}{ }^{4-}$ constructed by click chemistry.

This new compound $\mathbf{1 7}$ is a tweezer-type molecule with deoxycholic acid, 8-aminoquinoline, and 1,2,3triazole moieties. The 1,2,3-triazole moiety obtained via click chemistry allows the introduction of various functionalities and is a potential binding site for both metal ions and anions, ${ }^{36,37}$ which is very useful for multitarget analysis. The click reaction between steroidal diazides $15^{38}$ and quinoline terminal alkyne $16^{39}$ led to the fluorescent probe $\mathbf{1 7}$ (Scheme 5). This latter easily prepared probe could offer a simple and sensitive solventdependent assay method with low detection limits and fast response time for multi detection. Moreover, this probe showed strong fluorescence quenching upon binding to $\mathrm{Cu}^{2+}$ in acetonitrile $\left(\mathrm{CH}_{3} \mathrm{CN}\right)$ and water and gave also enhanced fluorescence response toward $\mathrm{C}_{2} \mathrm{O}_{4}{ }^{2-}$ and $\mathrm{P}_{2} \mathrm{O}_{7}{ }^{4-}$ in aqueous dimethyl sulfoxide (DMSO) solution. The results of tests to determine $\mathrm{Cu}^{2+}, \mathrm{C}_{2} \mathrm{O}_{4}{ }^{2-}$ and $\mathrm{P}_{2} \mathrm{O}_{7}{ }^{4-}$ on paper strips and in water samples proved the practical analytical utility of this probe.

In 2018, Negron-Silva et al. ${ }^{40}$ reported an efficient synthesis of a novel carbohydrate-lithocholic acid conjugate linked through 1,2,3-triazole rings and their derivatives.

The different steps of the synthesis are depicted in Scheme 6 . The readily available methyl $\alpha-D-$ glucopyranoside and the lithocholic acid were used as starting material to afford the methyl 4,6-Obenzylidene-2,3-di-O-propargyl $\alpha$-D-glucopyranoside $(\mathbf{1 8})^{41}$ and the methyl 3-azidolithocholate $19^{42}$ respectively. The click reaction between dipropargyl ether 18 and azide 19 under microwave irradiation at 100 ${ }^{\circ} \mathrm{C}$ with a $\mathrm{Cu}-\mathrm{Al}$ mixed oxide heterogeneous catalyst and sodium ascorbate led to the desired triazole-linked carbohydrate-bile acid conjugate 20 in a very short time (5 min) and a very good yield of 93\% (Scheme 6). 


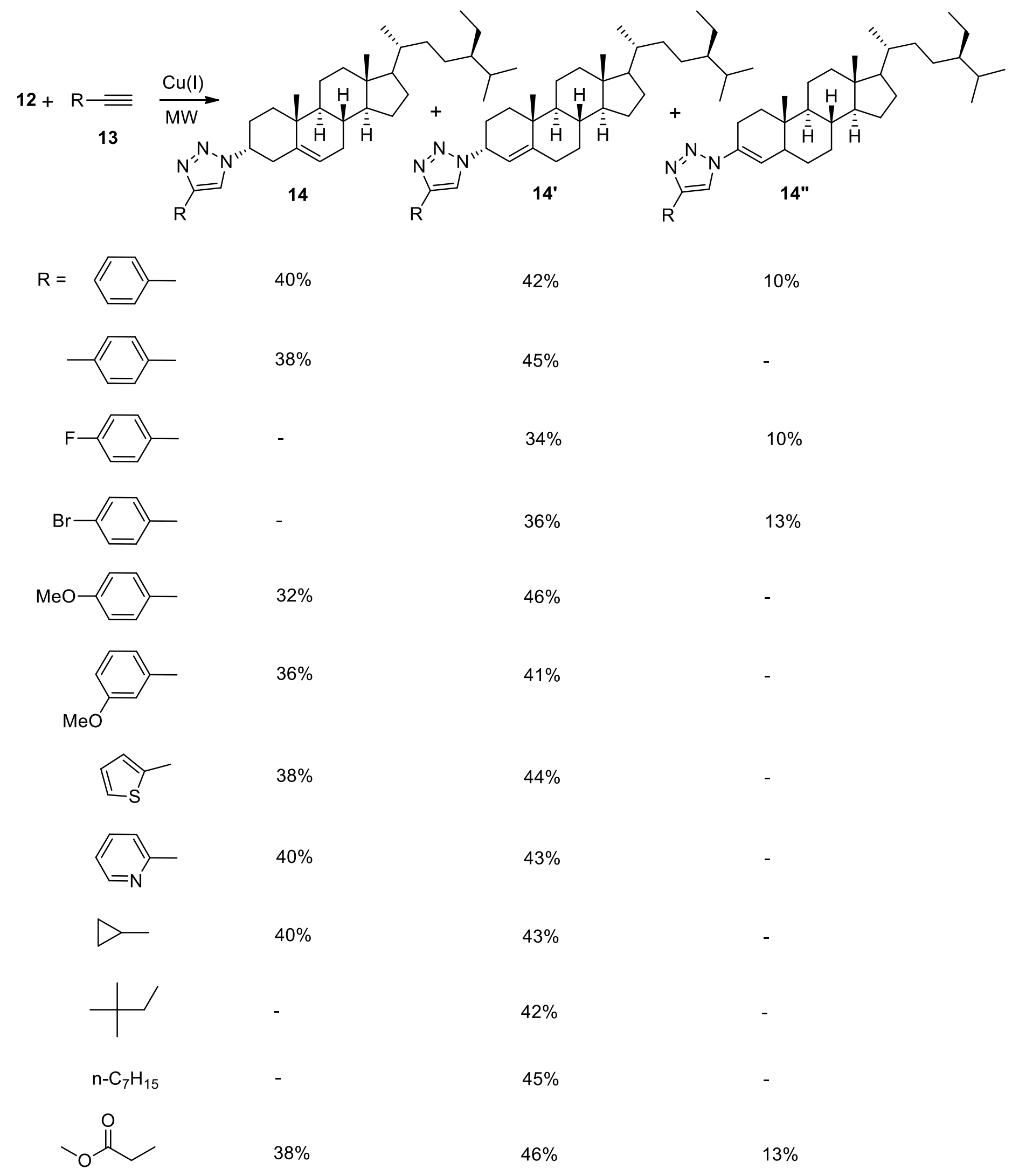

Reaction conditions: $\beta$-sitosterol-3-yl azide 12 , acetylenic derivative $13, \mathrm{CuSO}_{4} \cdot 5 \mathrm{H}_{2} \mathrm{O}$ and sodium ascorbate as the catalyst, in $5 \mathrm{~mL} \mathrm{H}_{2} \mathrm{O}$ at $40{ }^{\circ} \mathrm{C}$ for 30 min under microwave irradiation.

Scheme 4. Synthesis of $\beta$-sitosterol derivative 14 containing a 1,2,3-triazole substituent. 

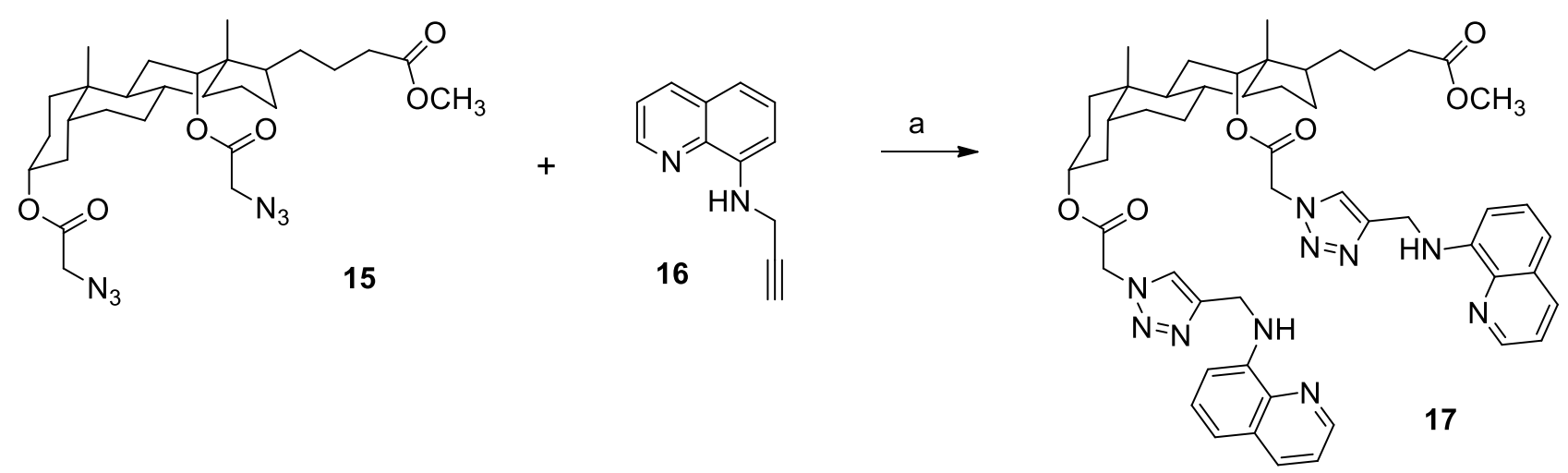

Reagents : a- $\mathrm{CuCl}_{2} \cdot 2 \mathrm{H}_{2} \mathrm{O}$, sodium ascorbate, $t \mathrm{BuOH} / \mathrm{H}_{2} \mathrm{O}$.

Scheme 5. The synthesis route of probe 17.<smiles>COC1C(O)C2OC(O)C1OC2CO</smiles>

methyl $\alpha$-D-glucopyranoside<smiles>C[C@H](CCC(=O)O)[C@H]1CC[C@H]2[C@@H]3CC[C@H]4C[C@@H](O)CC[C@]4(C)[C@H]3CC[C@@]21C</smiles>

lithocholic acid<smiles>C1=C[AsH2][AsH2]=C1</smiles><smiles>C#CCOC1COC2OC(c3ccccc3)COC1C2OC</smiles><smiles>COC(=O)CC[C@@H](C)[C@H]1CC[C@H]2[C@@H]3CC[C@H]4C[C@@H](N)CC[C@]4(C)[C@H]3CC[C@@]21C</smiles>

19

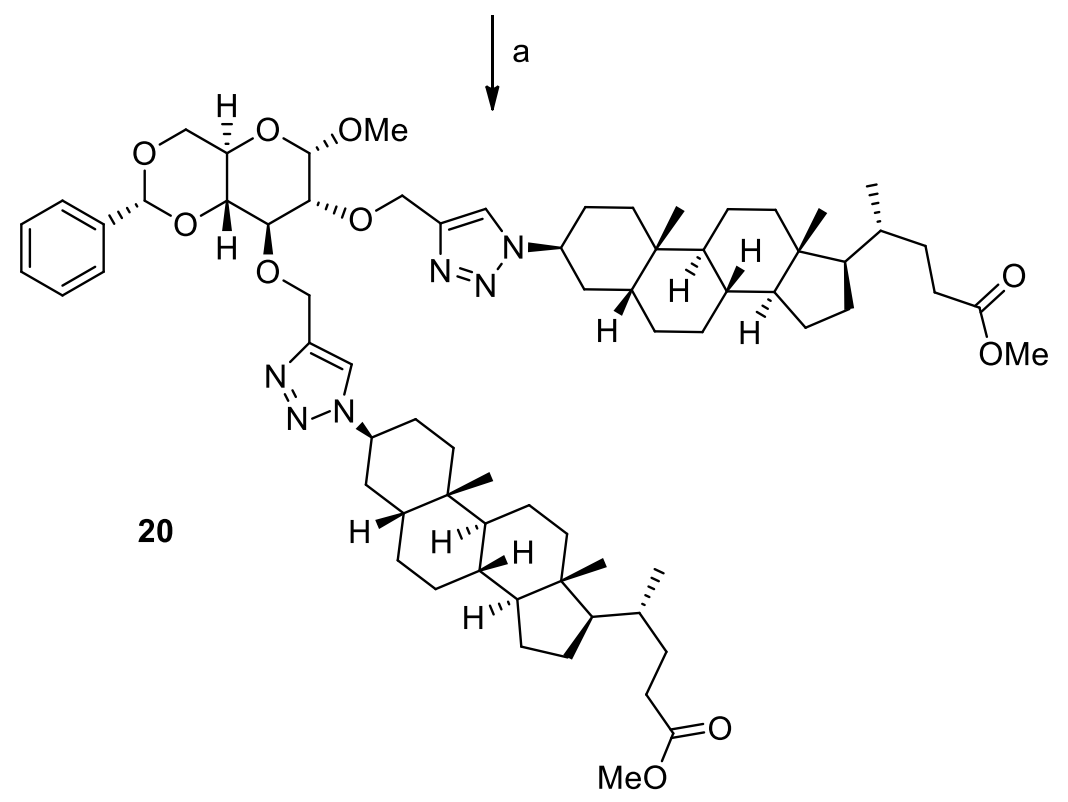

Reagents : a- Cu-Al mixed oxide, sodium ascorbate, EtOH- $\mathrm{H}_{2} \mathrm{O}(3: 1)$, $\mathrm{MW}, 30 \mathrm{~W}, 100^{\circ} \mathrm{C}, 5 \mathrm{~min}$.

Scheme 6. Synthesis of the triazole-linked carbohydrate-bile acid conjugate 20. 

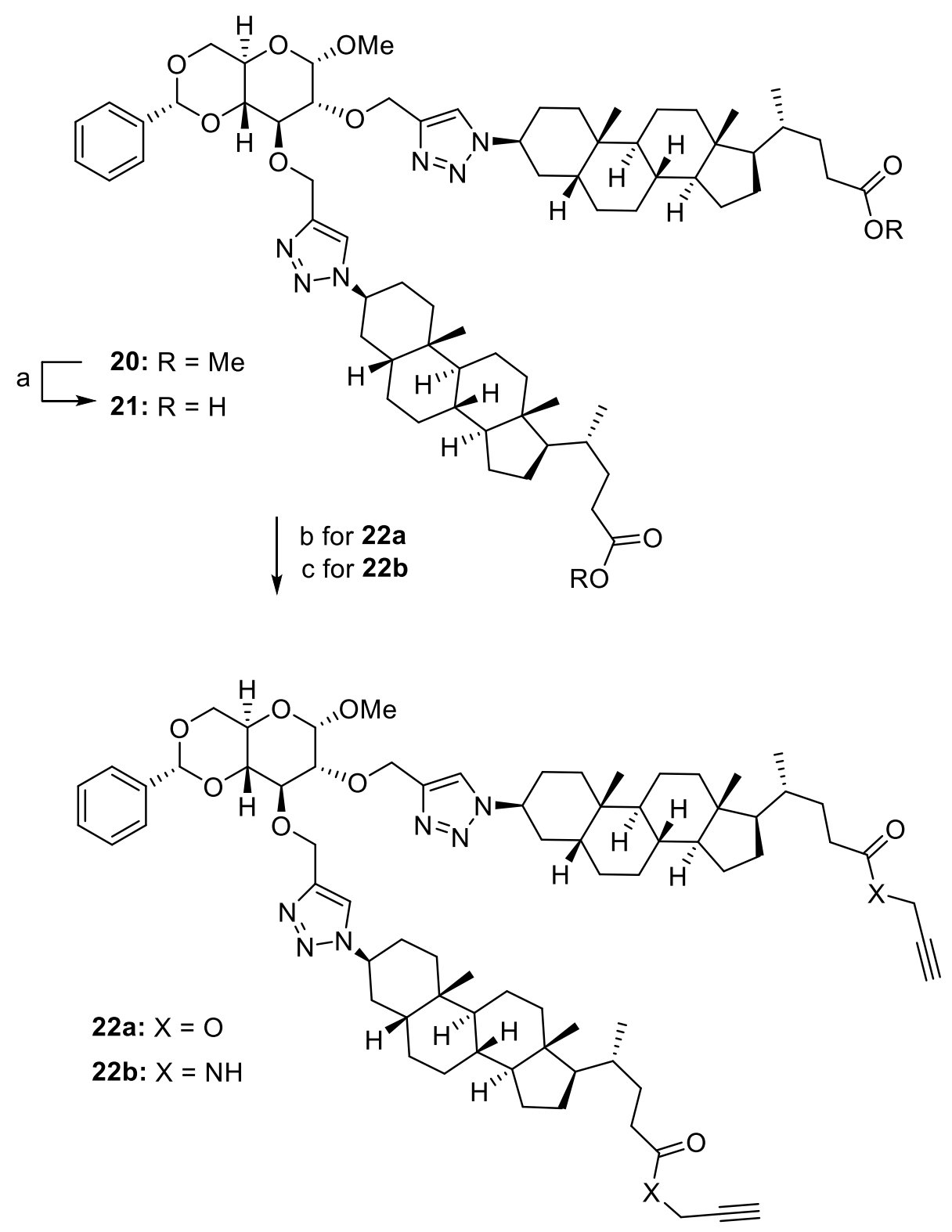

Reagents : a- 1. $\mathrm{NaOH} / \mathrm{H}_{2} \mathrm{O}, \mathrm{MeOH}$, 2. $\mathrm{H}_{3} \mathrm{O}^{+}$; b- 4-DMAP, EDC-HCl, $\mathrm{HOBt}$, propargyl alcohol, DMF; c- DIPEA, $\mathrm{ClCO}_{2} \mathrm{Et}$, propargylamine, THF.

Scheme 7. Synthesis of the propargyl ester $\mathbf{2 2 a}$ and propargylamide $\mathbf{2 2} \mathbf{b}$ derivatives.

To synthesize novel derivatives of $\mathbf{2 0}$, they decided to prepare targeted the propargyl ester $\mathbf{2 2 a}$ and propargylamide $\mathbf{2 2} \mathbf{b}$ derivatives.

The acid derivative $\mathbf{2 1}$ was synthesized from compound $\mathbf{2 0}$ by hydrolysis with $\mathrm{NaOH} / \mathrm{H}_{2} \mathrm{O} / \mathrm{MeOH}$ followed by acidification with $\mathrm{HCl} / \mathrm{H}_{2} \mathrm{O}$ in a $98 \%$ yield. The reaction of 21 with 4-DMAP, EDC-HCl, and $\mathrm{HOBt}$, or DIPEA and $\mathrm{ClCO}_{2} \mathrm{Et}$, followed by reaction with propargyl alcohol or propargylamine led to the corresponding ester $22 \mathrm{a}$ in $80 \%$ yield and amide $\mathbf{2 2} \mathbf{b}$ in $\mathbf{7 8 \%}$ yield, respectively (Scheme 7 ).

They decided to synthesize the compounds $\mathbf{2 4 a}$ and $\mathbf{2 4 b}$ by means of a second CuAAC (Scheme 8). According to the literature, ${ }^{43}$ they firstly prepared the 1 -azido-1-deoxy-2,3,4,6-tetra-O-acetyl- $\beta$-Dglucopyranoside $\mathbf{2 3}$. Then, the click reaction between propargyl derivative $\mathbf{2 2 a}$ or $\mathbf{2 2} \mathbf{b}$ and azide $\mathbf{2 3}$ under microwave irradiation at $80{ }^{\circ} \mathrm{C}$ with a Cu-Al mixed oxide heterogeneous catalyst and sodium ascorbate 
provided the corresponding compounds $\mathbf{2 4 a}$ and $\mathbf{2 4 b}$ in a very short time ( $5 \mathrm{~min}$ ) and very good yields of $78 \%$ and $72 \%$, respectively.

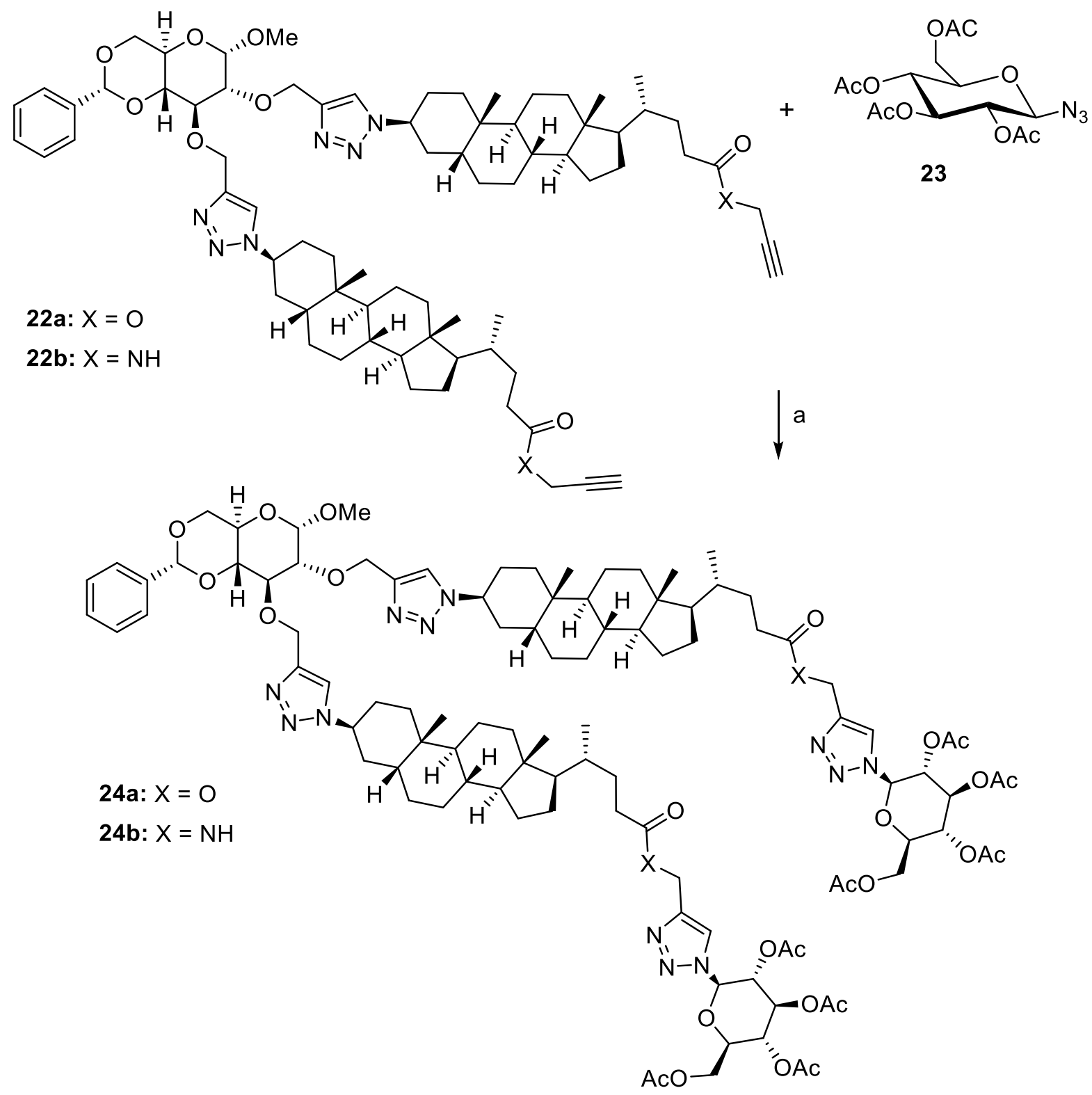

Reagents : a- Cu-Al mixed oxide, sodium ascorbate, EtOH- $\mathrm{H}_{2} \mathrm{O}(3: 1)$, $\mathrm{MW}, 30 \mathrm{~W}, 80^{\circ} \mathrm{C}, 5 \mathrm{~min}$

Scheme $\mathbf{8}$. Synthesis of derivatives $\mathbf{2 4 a}$ and $\mathbf{2 4 b .}$

Finally, the authors have performed the deprotection of the carbohydrate moiety of the compounds 24 in the presence of hydrochloric acid and using methanol as a solvent to afford the corresponding products $\mathbf{2 5}$ (Scheme 9).

In 2019, Huang et al. ${ }^{44}$ reported the synthesis of a series of novel steroidal $\beta$-triazolyl enones using the CUAAC click reaction and Claisen-Schmidt condensation reaction as the key steps. These new derivatives were further evaluated for their antiproliferative activity. 


\section{4a: $X=0$}

24b: $X=\mathrm{NH}$

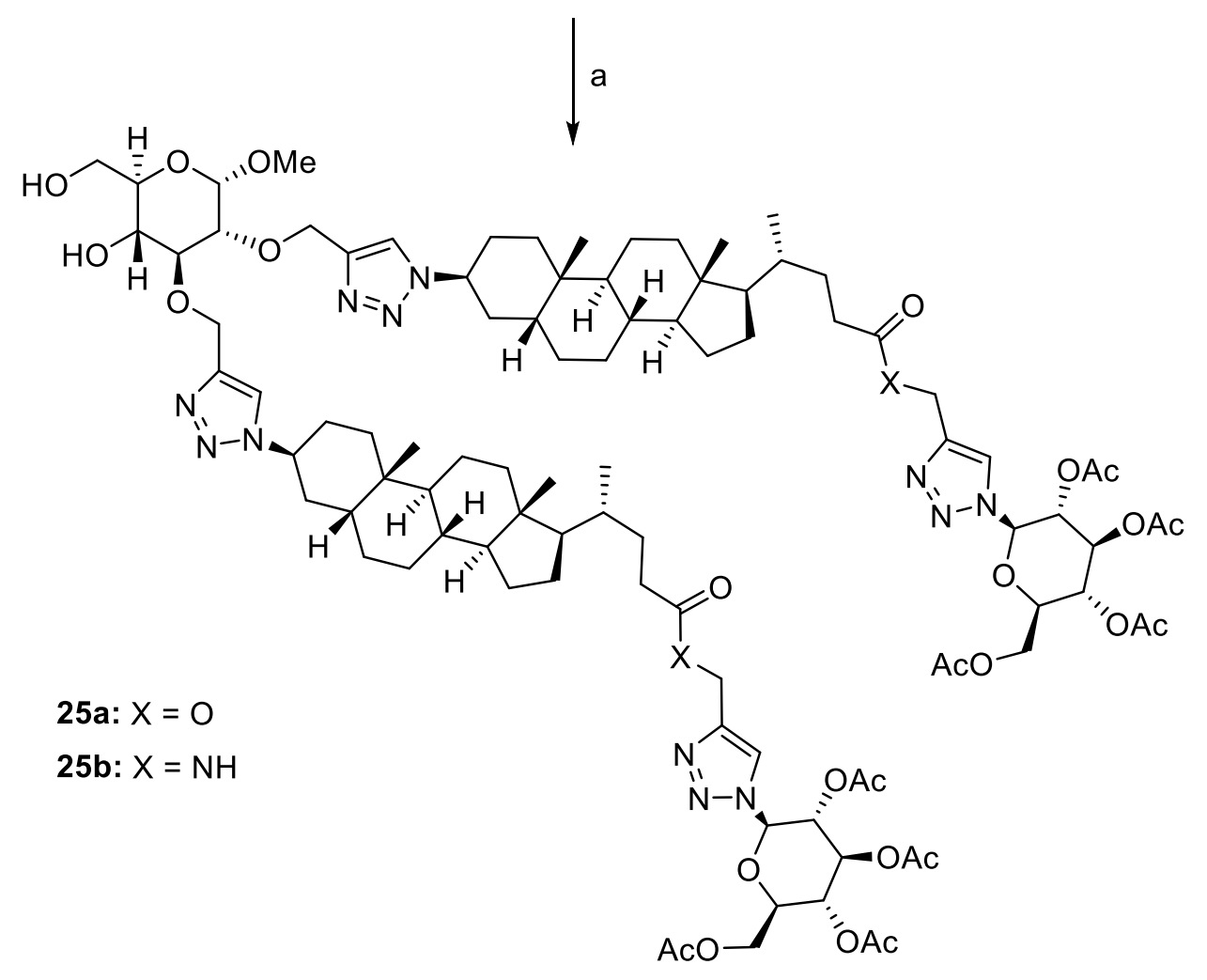

Reagents : a- $\mathrm{HCl}, \mathrm{MeOH}$, rt, overnight.

Scheme $\mathbf{9}$. Synthesis of derivatives $\mathbf{2 5 a}$ and $\mathbf{2 5 b .}$

The synthetic approach began with the preparation of compound $\mathbf{2 7}$ from aromatic amine $\mathbf{2 6}$ treated with $\mathrm{NaN}_{3}$ in the presence of $\mathrm{HCl}$ and $\mathrm{NaNO}_{2}$. The click reaction between azide 27 and 3,3-diethoxyprop-1-yne led to the corresponding triazole 28. Finally, using $\mathrm{KF} / \mathrm{Al}_{2} \mathrm{O}_{3}$ as the catalyst, the Claisen-Schmidt condensation between the aldehyde triazole $\mathbf{2 8}$ and androstanes provided the corresponding steroidal derivatives 29a-e and 30a-e in good yield (Scheme 10).

Most of these compounds showed good activity against a panel of cancer cells. In the case of compound 30a, the IC 50 values of 1.61 and $1.16 \mu \mathrm{M}$ against PC-3 and MGC-803 cells revealed a good antiproliferative activity. Moreover, this latter inhibited migration and invasion of gastric cancer cell line MGC-803 and prostate cancer cell line PC-3 in a dose-dependent manner. Notably, modifications of mRNA levels and protein expression of EMT markers were also observed. Consequently, this compound could be efficiently used to prepare new anticancer molecules to inhibit cell invasion. 
<smiles>Nc1c[X]:[R]cc1</smiles>

26
$\mathrm{I}_{\mathrm{x}}^{\mathrm{N}} \mathrm{R} \stackrel{\mathrm{b}}{\longrightarrow}$

27

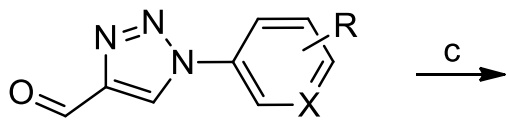

28<smiles>[R]c1ccc(-n2cc(C=C3CC4C5CCC6C[C@@H](O)CC[C@]6(C)C5CC[C@]4(C)C3=O)nn2)cc1</smiles>

29a-e<smiles>[R][X]c1cccc(-n2cc(C=C3CC4C5CC=C6C[C@@H](O)CC[C@]6(C)C5CC[C@]4(C)C3=O)nn2)c1</smiles>

30a-e

Reagents : a- $\mathrm{HCl}, \mathrm{NaNO}_{2}$, sodium azide, ice bath; b- 1. 3,3-diethoxyprop-1-yne, $\mathrm{CuSO}_{4} \cdot 5 \mathrm{H}_{2} \mathrm{O}$, sodium azide, $\mathrm{H}_{2} \mathrm{O} / \mathrm{THF}(1: 1)$, 2. formic acid; c- steroidal derivative, $\mathrm{KF}_{\mathrm{A}} \mathrm{Al}_{2} \mathrm{O}_{3}(1: 1)$, $\mathrm{EtOH}$, reflux for $5 \mathrm{~h}$.

Scheme 10. Synthesis of compounds 29a-e and 30a-e.

The same year, Griffith et al. ${ }^{45}$ described the synthesis of the novel 1,4 disubstituted 1,2,3 triazole and estrogen-based ligand 2-(4-(estradiol-17-yl)-1H-1,2,3-triazol-1-yl)propane-1,3-diamine, EDiolDap, by the CuAAC click reaction between $17 \alpha$-ethynylestradiol and di-tert-butyl (2-azidopropane-1,3-diyl)dicarbamate (Scheme 12).

(2-(4-(Estradiol-17-yl)-1H-1,2,3-triazol-1-yl)propane-1,3-diamine) dihydrochloride 32 was synthesised in two steps as indicated in Scheme 11. Firstly, the click reaction between $17 \alpha$-ethynylestradiol and di-tert-butyl (2-azidopropane-1,3-diyl)dicarbamate using standard conditions led to the corresponding triazole 31 (di-tertbutyl (2-(4-(estradiol)-1H-1,2,3-triazol-1-yl)propane-1,3-diyl)dicarbamate) in excellent yield (97\%). Then, this latter was deprotected using $\mathrm{HCl}$ to provide 2-(4-(estradiol)-1H-1,2,3-triazol-1-yl)propane-1,3-diamine dihydrochloride 32 in $95 \%$ yield.

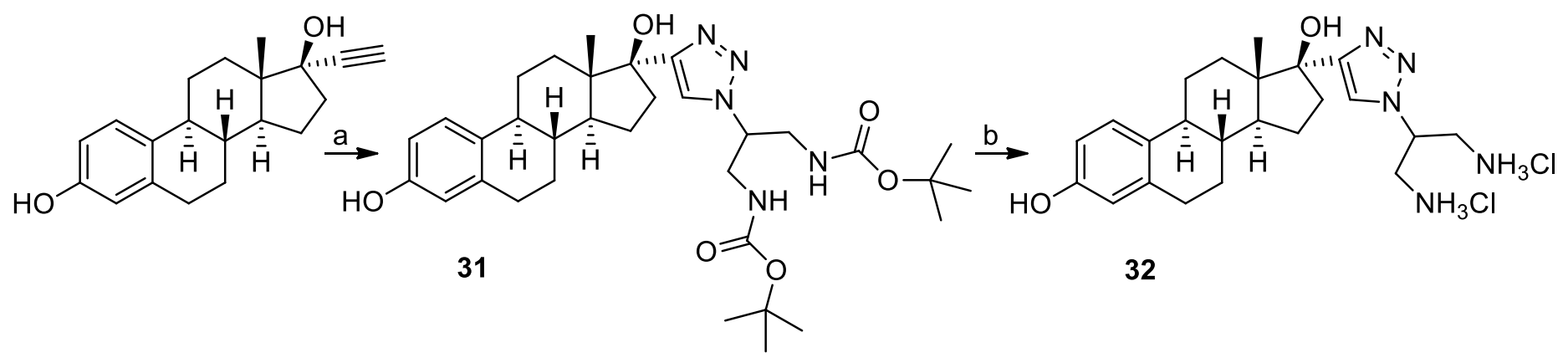

Reagents : a- $1: 4 \mathrm{MeOH}: \mathrm{H}_{2} \mathrm{O}, \mathrm{CuSO}_{4} \cdot 5 \mathrm{H}_{2} \mathrm{O}$, sodium ascorbate, $48 \mathrm{~h}, 40{ }^{\circ} \mathrm{C} ; \mathrm{b}-1: 1 \mathrm{EtOAc}: \mathrm{HCl}(6 \mathrm{M}), 2 \mathrm{~h}$, rt.

Scheme 11. Synthesis of di-tert-butyl(2-(4-(estradiol)-1H-1,2,3-triazol-1-yl)propane-1,3-diyl)dicarbamate 31 by CuAAC and $\mathrm{HCl}$ deprotection of $\mathbf{3 1}$ led to 2-(4-(estradiol)-1H-1,2,3-triazol-1-yl)propane-1,3-diamine dihydrochloride 32. 
The dihydrochloride 32 was then treated with two equivalents of base (1,8-diazabiciclo[5.4.0]undec-7-ene or $\mathrm{NaOH}$ ) followed by $\mathrm{Pt}(\mathrm{II})$ dimethylsulfoxido precursor complexes ${ }^{46}$ to afford novel Pt(II) estradiol complexes (Scheme 12). The dichlorido-Pt(II) estradiol complex, $\left[\mathrm{PtCl}_{2}\right.$ (EDiolDap)] 35 was isolated in $58 \%$ yield and the 1,1-cyclobutanedicarboxylato-Pt(II) estradiol complex, [Pt(CBDCA)(EDiolDap)] 36 in 74 yield.

An estrogen receptor-negative ER-colon cancer cell line and a panel of estrogen receptor-positive ER+cancer cell lines were used to find in vitro cytotoxicity of both estrogen-linked Pt(II) complexes. It is worth pointing out that their in vitro cytotoxic effect is 30 times greater against ER+ cancer cell lines than against the ERcolon cancer line. The authors observed that these two complexes presented superior in vitro cytotoxicity than cisplatin. Moreover, it is interesting to note that the test results in vivo are better than those obtained with the clinically used cisplatin. These novel estrogen-linked Pt(II) complexes exhibit in vitro cytotoxic results which are very promising to develop such complexes.

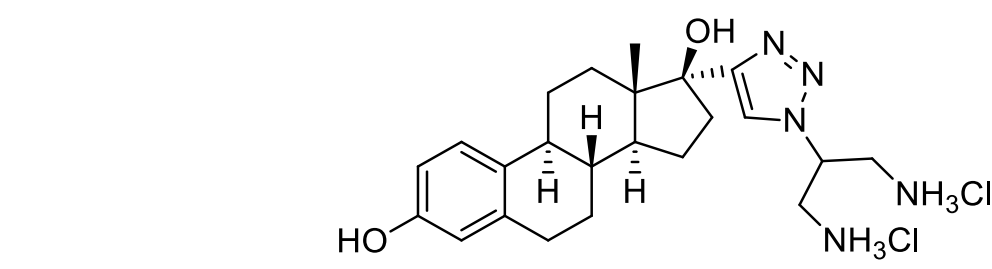<smiles>CS(=O)(=O)[P+](Cl)(Cl)=S(C)(C)=O</smiles>

33
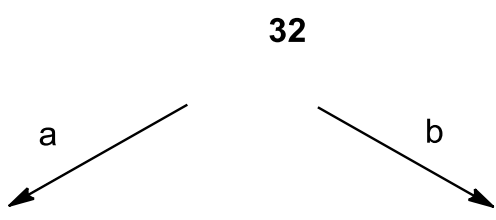

32
34<smiles>CS(C)(=O)=[P+]1C(=O)OC2(CCC2)OC1=O</smiles><smiles>C[C@]12CC[C@@]3(C)c4ccc(O)cc4CC[C@]3(C)[C@@H]1CC[C@@]2(O)c1cn(C2CN[P](Cl)(Cl)NC2)nn1</smiles><smiles>C[C@]12CCc3cc(O)ccc3[C@@H]1CC[C@@]1(C)[C@H]2CC[C@]1(O)c1cn(C2CCN[P+]3(NC2)OC(=O)C2(CCC2)C(=O)O3)nn1</smiles>

36

Reagents : a- DMF, DBU, 33, 2 days, rt; b- $\mathrm{H}_{2} \mathrm{O}, \mathrm{DMF}, \mathrm{NaOH}, 34,10{ }^{\circ} \mathrm{C}, 6 \mathrm{~h}$.

In 2019, Pérez-Campos et al. ${ }^{47}$ reported the activity of first and second-generation dendrimers over $T$. cruzi in the epimastigote stage. $\alpha$-Ethynylestradiol (EE) modified with PAMAM-type dendrons was used to prepare dendrimers. The key reaction of this synthesis is a click reaction.

As depicted in Scheme 13, the copper-catalyzed azide-alkyne cycloaddition (CuAAC) of $17 \alpha$-ethynylestradiol and the azide derivative $\mathbf{3 8}$ afforded the corresponding triazole $\mathbf{3 9}$ in good yield. In a second step, this latter was deprotected with TFA leading to the desired steroidal derivative $\mathbf{4 0 .}$ 
<smiles>C#C[C@]1(O)CCC2C3CCc4cc(O)ccc4C3CC[C@@]21C</smiles>

37
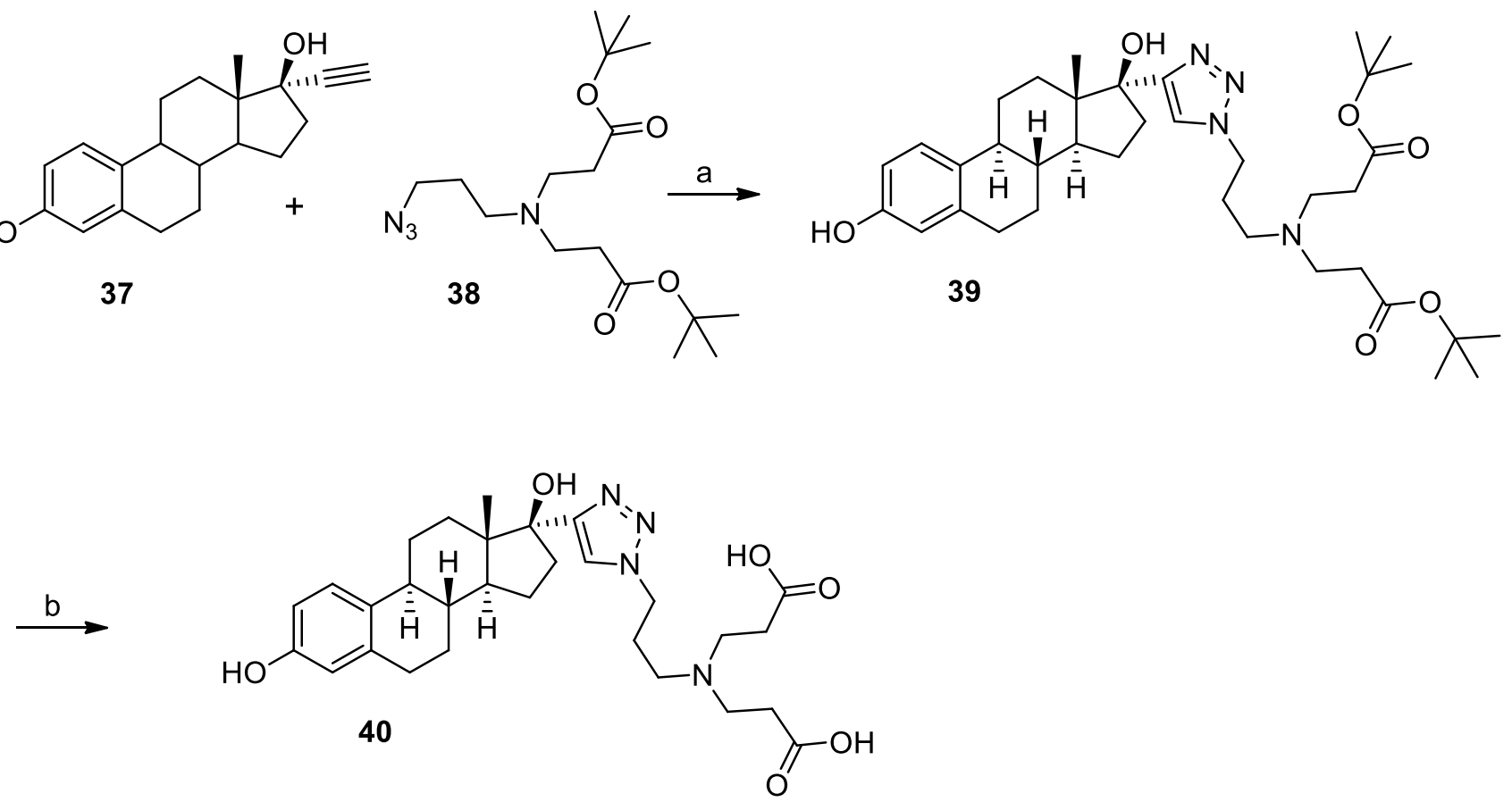

Reagents : a- $\mathrm{CuSO}_{4} \cdot 5 \mathrm{H}_{2} \mathrm{O}$, sodium ascorbate, benzoic acid, $t \mathrm{BuOH}: \mathrm{H}_{2} \mathrm{O}, 12 \mathrm{~h}, \mathrm{rt}$; b- TFA, rt, 2 h.

Scheme 13. Route of synthesis of dendron $\mathbf{4 0 .}$

Dendrimers $\mathbf{4 1}$ and $\mathbf{4 2}$, the structures of which are shown in Scheme 14, were synthesized by a previously described procedure ${ }^{48}$ from dendron 40.

Flow cytometry was used to determine the activity of each compound, including benznidazole (Bz) as positive control. The authors observed that a concentration of $14.8 \mu \mathrm{mol} / \mathrm{mL}$ of the second-generation dendrimer is more efficient than $\mathrm{Bz}$ in the time with an $\mathrm{IC}_{50}=1.25 \pm 0.19 \mu \mathrm{mol} / \mathrm{mL}$. Moreover, using dendrimers, cell death in T. cruzi epimastigotes was mostly done via apoptosis and not via necrosis as observed with Bz in more than half of cells.

In 2020, Wimmer et al. ${ }^{49}$ reported the synthesis and pharmacological effects of diosgenin-betulinic acid conjugates. They are shown to enhance the pharmacological effects of their components.

The synthetic approach is depicted in Scheme 15. Firstly, compound $\mathbf{4 3}$ was converted into its benzyl ester 44 by treatment with benzyl bromide in DMF in good yield. In a second step, the derivative $\mathbf{4 4}$ possessing a hydroxyl group at C-3 was treated with propargyl bromide in THF, using sodium hydride as a base, to provide the corresponding propargyl ether 45. In the newt step, the 1,2,3-triazole derivative 46 was synthesized via copper-catalyzed azide-alkyne cycloaddition (CuAAC) from alkyne $\mathbf{4 5}$ and azidovaleric acid using copper(II) sulfate as a catalyst. Deprotection of the benzyl group of $\mathbf{4 6}$ by high-pressure hydrogenation using Pd/C (10\%) led to the corresponding steroidal derivative $\mathbf{4 7}$ in a good yield.

The steroidal derivative $\mathbf{4 6}$ was also used to prepare the diosgenin conjugate 48 using 4(dimethylamino)pyridine (DMAP) to enhance the reaction and $N, N^{\prime}$-dicyclohexylcarbodiimide (DCC) as coupling agent (Scheme 15). In a final step, this latter was deprotected by hydrogenation (10\% Pd/C) leading to the target diosgenin-betulinic acid conjugate $\mathbf{4 9}$ in an excellent yield.

No cytotoxicity in the tested cancer cell lines was observed for the betulinic acid 43, the intermediates 44 and $\mathbf{4 5}$, and the diosgenin conjugate $\mathbf{4 9}$. On the other hand, the diosgenin conjugate 48 exhibited selective 
cytotoxicity in human T-lymphoblastic leukemia (CEM) cancer cells with an $\mathrm{IC}_{50}=6.5 \pm 1.1$ ? $\mathrm{M}$, and compound 46 exhibited medium multifarious cytotoxicity in tested human cell lines.
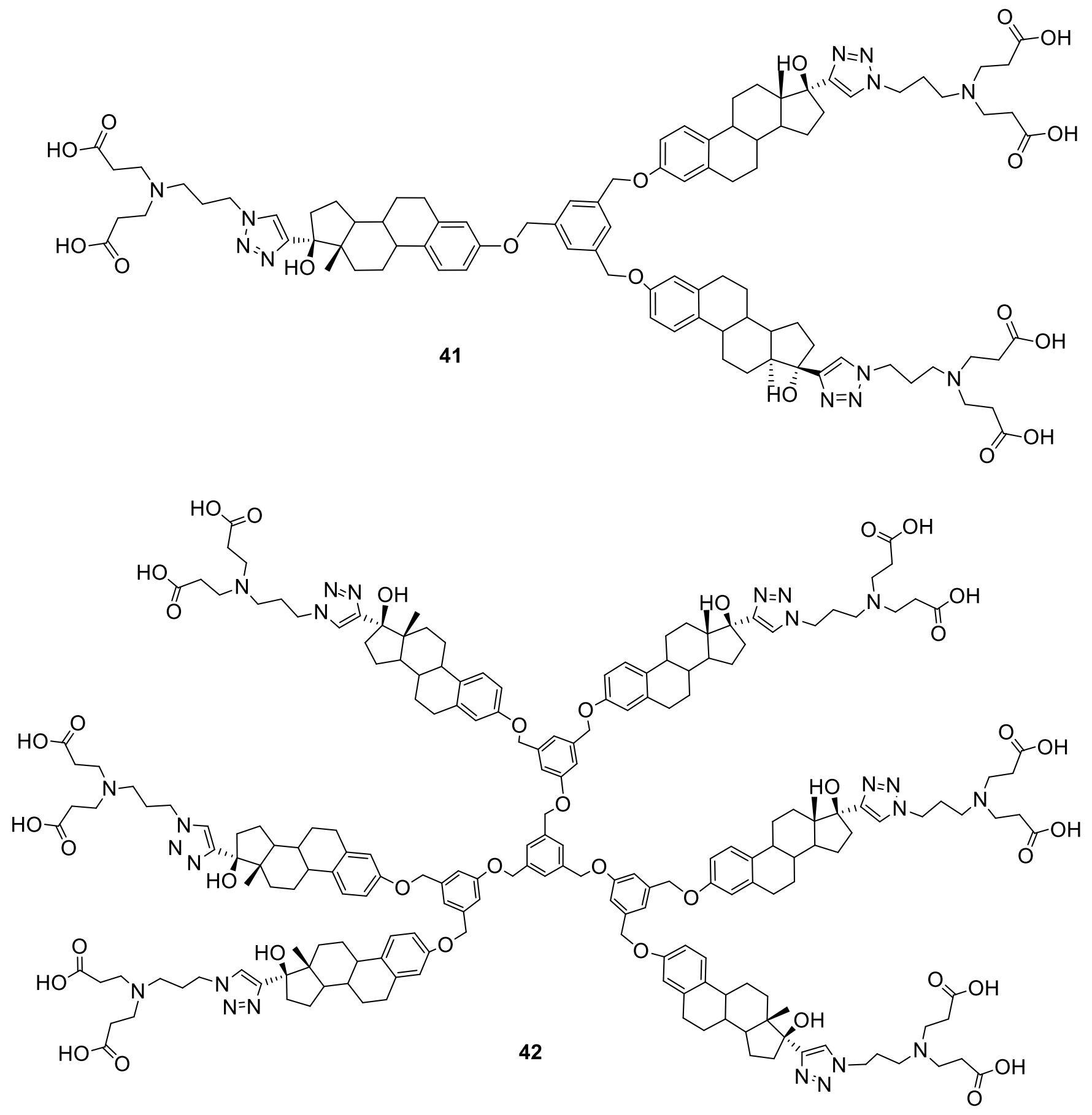

Scheme 14. Structures of dendrimers 41 and 42. 


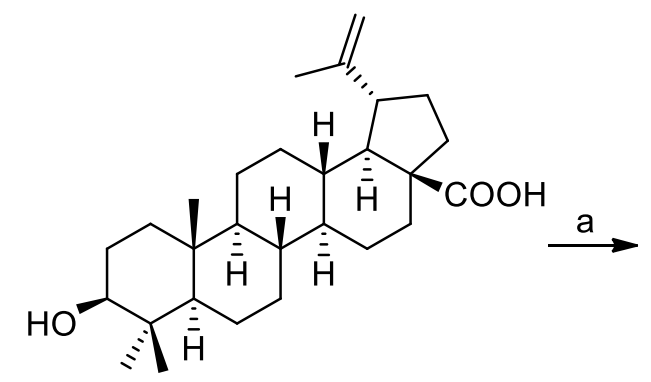

43

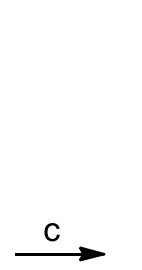<smiles>C=C(C)[C@H]1CC[C@]2(C(=O)OCc3ccccc3)CC[C@H]3[C@H]4CC[C@H]5C(C)(C)[C@@H](O)CC[C@]5(C)[C@H]4CC[C@H]3[C@H]12</smiles>

44

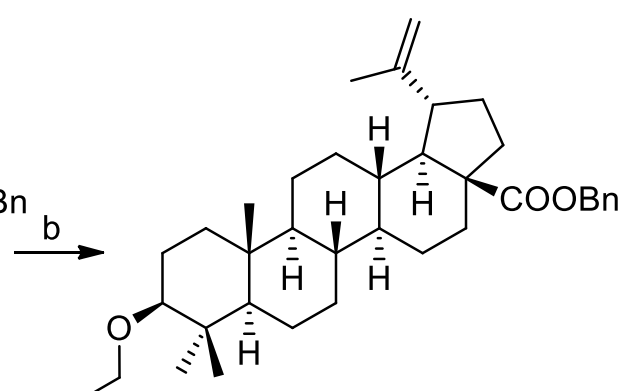

45

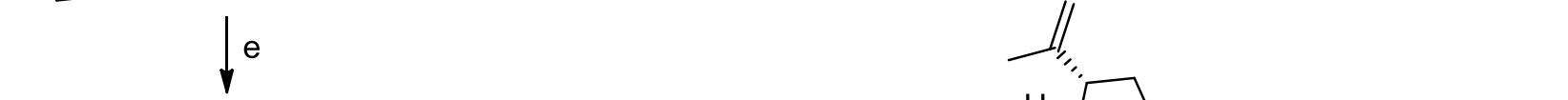

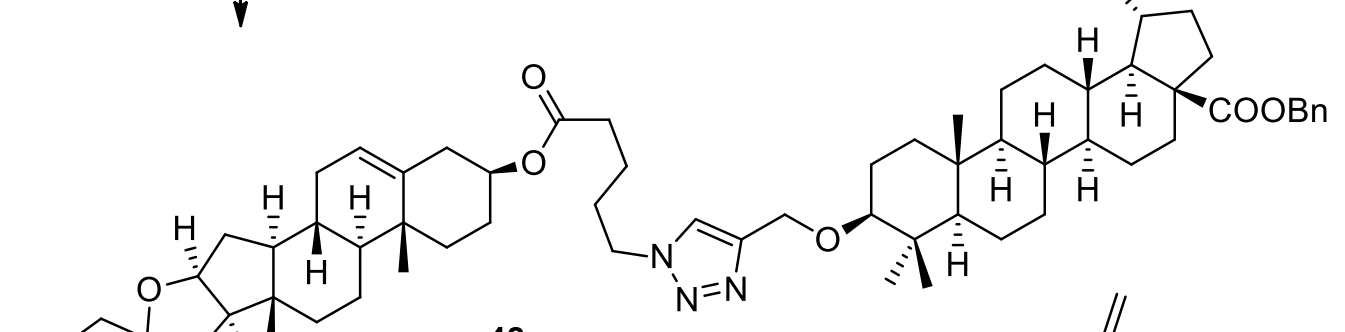

48<smiles>CCC(C)[C@H]1CC[C@@H](C)CO1</smiles><smiles>[V][I+]</smiles>

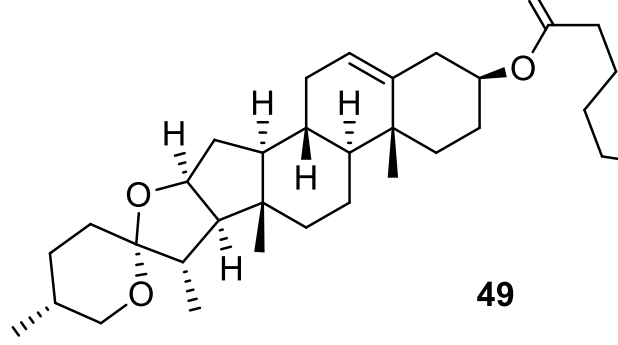

Reagents: a- $\mathrm{BnBr}, \mathrm{K}_{2} \mathrm{CO}_{3}$, DMF; b- propargyl bromide, $\mathrm{NaH}$, THF; c- azidovaleric acid, $\mathrm{CuSO}_{4} \cdot 5 \mathrm{H}_{2} \mathrm{O}, \mathrm{NaAsc}$, $\mathrm{H}_{2} \mathrm{O} / \mathrm{CH}_{2} \mathrm{Cl}_{2}$; d- $\mathrm{H}_{2} \mathrm{Pd} / \mathrm{C}, 130 \mathrm{kPa}$, EtOH/THF; e- DCC, $\mathrm{CH}_{2} \mathrm{Cl}_{2}$; f- $\mathrm{H}_{2} \mathrm{Pd} / \mathrm{C}, 130 \mathrm{kPa}$, EtOH/THF.

Scheme 15. Synthesis of diosgenin-betulinic acid conjugates.

The same year, Acik et al. ${ }^{50}$ described a method to deposit most common bile acids such as lithocholic acid (LCA) and chenodeoxycholic acid (CDCA) bearing poly(vinyl chloride) nanofiber (PVC-LCA and PVC-CDCA) coatings on glass slides surface using a combination method by employing copper(I)-catalyzed azide-alkyne cycloaddition 'click' reaction (CuAAC), followed by electrospinning process. 
The synthetic route to prepare PVC-LCA or PVC-CDCA was depicted in Scheme 16. Treatment of PVC with sodium azide provided the corresponding azide PVC-N $\mathrm{N}_{3}$ in good yield. To limit side reactions, LCA and CDCA were firstly converted into their corresponding ester $\mathbf{5 0}$ and $\mathbf{5 1}$ using acetyl chloride, followed by a reaction with 4-pentyonic acid to give the clickable LCA-alkyne $\mathbf{5 2}$ and CDCA-alkyne 53, respectively. In a final step, the click reaction between these latter and PVC- $\mathrm{N}_{3}$ led to the corresponding PVC-LCA and PVC-CDCA. After these syntheses, electrospun nanofibers were obtained from their solutions by using a simple electrospinning technique at room temperature.

Electrospinnability, thermal properties, and the hydrophilicity were enhanced by introducing LCA and CDCA moieties into PVC. These novel steroidal PVC nanofibers could be interesting to produce PVC materials useful in bio-applications.

PVC<smiles>CCCC(C)C(C)C(C)C</smiles><smiles>[13CH3]</smiles>

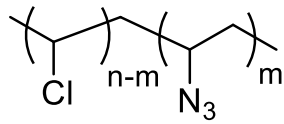

PVC-N 3

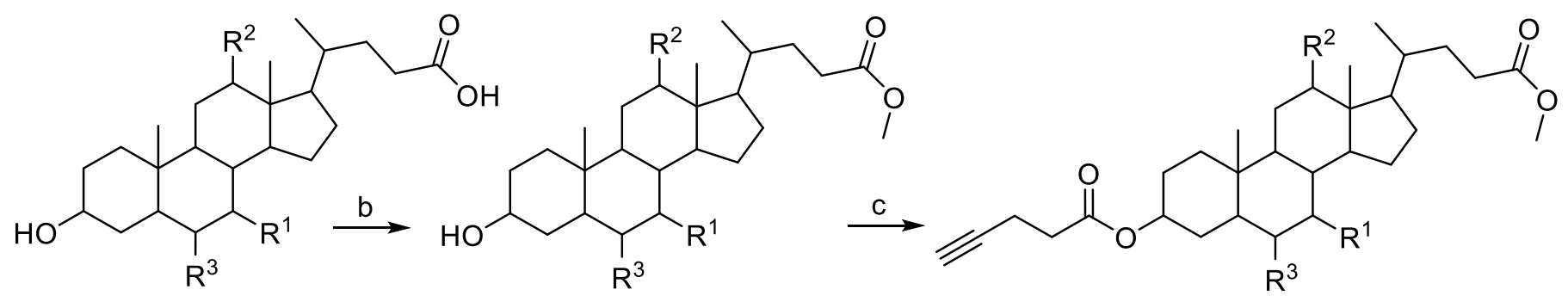

LCA: $\mathrm{R}^{1}=\mathrm{R}^{2}=\mathrm{R}^{3}=\mathrm{H}$ CDCA: $\mathrm{R}^{1}=\mathrm{OH} \mathrm{R}^{2}=\mathrm{R}^{3}=\mathrm{H}$
$50 \mathrm{R}^{1}=\mathrm{R}^{2}=\mathrm{R}^{3}=\mathrm{H}$

$51 \mathrm{R}^{1}=\mathrm{OH} \mathrm{R} \mathrm{R}^{2}=\mathrm{R}^{3}=\mathrm{H}$
$52 \mathrm{R}^{1}=\mathrm{R}^{2}=\mathrm{R}^{3}=\mathrm{H}$

$53 \mathrm{R}^{1}=\mathrm{OH} \mathrm{R}^{2}=\mathrm{R}^{3}=\mathrm{H}$

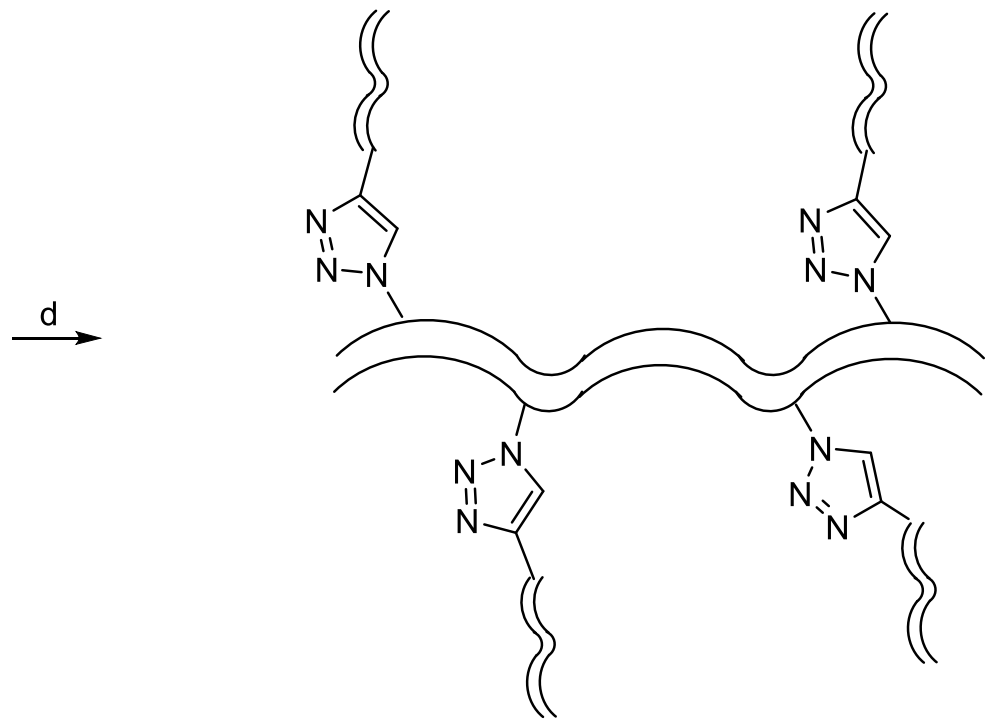

PVC-LCA: $\mathrm{R}^{1}=\mathrm{R}^{2}=\mathrm{R}^{3}=\mathrm{H}$ PVC-CDCA: $\mathrm{R}^{1}=\mathrm{OH} \mathrm{R}^{2}=\mathrm{R}^{3}=\mathrm{H}$

Reagents : a- $\mathrm{NaN}_{3}$, DMF, $\mathrm{H}_{2} \mathrm{O}, 60^{\circ} \mathrm{C}$; b- $\mathrm{CH}_{3} \mathrm{COCl}, \mathrm{CH}_{3} \mathrm{OH}, \mathrm{O}^{\circ} \mathrm{C}$; c- 4-pentyonic acid, DCC, DMAP, $\mathrm{CH}_{2} \mathrm{Cl}_{2}, 0^{\circ} \mathrm{C}$; d- $\mathrm{CuBr}$, PMDETA, DMF, $50^{\circ} \mathrm{C}, 24 \mathrm{~h}$.

Scheme 16. The synthetic route for preparing PVC-LCA or PVC-CDCA and their precursors. 


\section{Conclusions}

The syntheses of steroids reported in the literature from 2016 to mid-2021, using the CuAAC "click" reaction, have been reviewed. The growing use of the copper-catalyzed azide-alkyne cycloaddition (CuAAC) has enabled chemists to make simple syntheses of increasingly complex and elaborate steroid molecules. Some of these syntheses deserve to be studied further. This route is particularly advantageous for the preparation of steroids with potential biological activity. Overall, the very great structural diversity and the biological capacities of these molecules encourage researchers to go even further in this field.

\section{Acknowledgements}

This work has been financially supported by the CNRS and the Ministère de l'Enseignement Supérieur et de la Recherche.

\section{References}

1. Zeelen, J. F. Medicinal chemistry of steroids; Elsevier: Amsterdam, Netherlands, 1990.

2. Träger, L. F. Steroidhormone; Springer: Berlin, 1977.

3. Biellmann, J. F. Chem. Rev. 2003, 103, 2019. http://doi.org/10.1021/cr020071b

4. Nising, C. F.; Bräse, S. Angew. Chem. Int. Ed. 2008, 47, 9389. https://doi.org/10.1002/anie.200803720

5. Hanson, J. R. Nat. Prod. Reports 2010, 27, 887. https://doi.org/10.1039/C001262A

6. Kallander, L. S.; Lu, Q.; Chen, W.; Tomaszek, T.; Yang, G.; Tew, D.; Meek, T. D., Hofmann, G.A.; SchulzPritchard, C.K.; Smith, W.W.; Janson, C.A., Ryan, M. D., Zhang, G. F.; Johanson, K. O.; Kirkpatrick, R. B.; Ho, T. F.; Fisher, P. W.; Mattern, M. R.; Johnson, R. K.; Hansbury, M. J.; Winkler, J. D.; Ward, K. W.; Veber, D. F.; Thompson, S.K. J Med Chem 2005, 48, 5644. https://doi.org/10.1021/jm050408c

7. Silva, F. C.; Souza, M. C. B. V.; Frugulhetti, I. I. P.; Castro, H. C.; Souza, S. L. O.; Souza, T. M. L.; Rodrigues, D. Q.; Souza, A. M. T.; Abreu, P. A.; Passamani, F.; Rodrigues, C. R.; Ferreira, V. F. Eur. J. Med. Chem. 2009, 44, 373.

https://doi.org/10.1016/j.ejmech.2008.02.047

8. Costa, M. S.; Boechat, N; Rangel, E. A.; Silva, F. C.; Souza, A. M. T.; Rodrigues, C. R.; Castro, H. C.; Junior, I. N.; Lourenço, M. C. S.; Wardell, S. M. S. V; Ferreira, V. F. Bioorg. Med. Chem. 2006, 14, 8644. https://doi.org/10.1016/j.bmc.2006.08.019

9. Wang, X. L.; Wan, K; Zhou, C. H. Eur J Med Chem 2010, 45, 4631. https://doi.org/10.1016/j.ejmech.2010.07.031

10. Adibekian, A.; Martin, B. R.; Wang, C.; Hsu, K. L.; Bachovchin, D. A.; Niessen, S.; Hoover, H.; Cravatt, B. F. Nature Chem. Biol. 2011, 7, 469. https://doi.org/10.1038/nCHeMBIO.579

11. Bock, V. D.; Speijer, D.; Hiemstra, H.; van Maarseveen, J. H. Org. Biomol. Chem. 2007, 5, 971. 
https://doi.org/10.1039/B616751A

12. Krulle, T. M.; Fuente, C. D.; Pickering, L.; Aplin, R. T.; Tsitsanou, K. E.; Zographos, S. E.; Oikonomakos, N. G.; Nash R. J, Griffiths R. C, Fleet G. W. Tetrahedron Asymm. 1997, 8, 3807.

https://doi.org/10.1021/jm050408c

13. Dalvie, D. K.; Kalgulkar, S. C.; Obach, R. S.; O’Donnell, J. P. Chem. Res. Toxicol. 2002, 15, 269. https://doi.org/10.1021/tx015574b

14. Horne, W. S.; Yadav, M. K.; Stout, C. D., Ghadiri, M. R. J. Am. Chem. Soc. 2004, 126, 15366. https://doi.org/10.1021/ja0450408

15. Imtiyaz, H. L.; Khaliquz, Z. K.; Bharat, I. F.; Fida, H. Steroids 2013, 78, 945. https://doi.org/10.1016/j.steroids.2013.05.015

16. Zhungietu, G. I.; Dorofeenko, G. N. Russ. Chem. Rev. 1967, 36, 24.3 https://doi.org/10.1070/RC1967v036n01ABEH001581

17. Li, Y.; Huang, J.; Liu, J.L.; Yan, P. Y.; Liu, H.; Sun, Q. Steroids 2011, 76, 1615. https://doi.org/10.1016/i.steroids.2011.10.003

18. Rafat, M. M.; Wagnat, W. W.; Gamal, A. E.; Rehab, M. S. A. Steroids 2012, 77, 1560. https://doi.org/10.1016/i.steroids.2012.09.004

19. Dwipen, K.; Rupak, K. S.; Ratul, S.; Nabin, C. B.; Jadab, C. S. Steroids 2013, 78, 321. https://doi.org/10.1016/j.steroids.2012.12.003

20. Ranju, B.; Pratap, C. A. Steroids 2012, 77, 552. https://doi.org/10.1016/j.steroids.2012.01.020

21. Duha, C. Y.; Loa, I. W.; Wang, S. K.; Dai, C. F. Steroids 2007, 72, 573. https://doi.org/10.1016/i.steroids.2007.03.010

22. Ibrahim-Ouali, M.; Santelli M. Steroids 2006, 71, 1025. https://doi.org/10.1016/i.steroids.2006.09.006

23. Hanson, J. R. Steroids: partial synthesis in medicinal chemistry. Nat. Prod. Rep. 2006, 23, 100. https://doi.org/10.1039/B512848J

24. Chen, S. J.; Cui, J. G.; Li, Y.; Fan, L. H. Chin. J. Org. Chem. 2011, 187. http://sioc-journal.cn/Jwk_yjhx/EN/Y2011/V31/I02/187

25. Zhang, X. J.; Cui, J. G.; Li, Y.; Chen, S. J. Chin. J. Org. Chem. 2010, 30, 655. http://sioc-journal.cn/Jwk yjhx/EN/Y2010/V30/105/655

26. Stulov, S. V.; Misharin A. Y. Chem. Heterocycl. Compd. 2013, 48, 1431. https://doi.org/10.1007/s10593-013-1158-8

27. Ma, B.; Xiao, Z. Y.; Chen, Y. J.; Lei, M.; Meng, Y. H.; Guo, D. A. Steroids 2013, $78,508$. https://doi.org/10.1016/i.steroids.2013.02.007

28. Guo, H.; Zhang, G. L.; Zhang, T., He, X. R.; Wu, Z. Y.; Xiao, Y. L.; Pan, Y.; Qiu, G.; Liu, P.; Hu, X. Eur. J. Med. Chem. 2011, 46, 3662.

https://doi.org/10.1016/j.ejmech.2011.05.030

29. Huang, L. H.; Zheng, Y. F.; Lu, Y. Z.; Song, C. J.; Wang, Y. G.; Yu, B.; Liu, H. M. Steroids 2012, $77,710$. https://doi.org/10.1016/j.steroids.2012.03.002

30. Kovács, D.; Mótyán, G.; Wölfling, J.; Kovács, I.; Zupkó, I.; Frank, É. Bioorg. Med. Chem. Lett. 2014, $24,1265$. https://doi.org/10.1016/j.bmcl.2014.01.069

31. Ibrahim-Ouali, M.; Dumur, F. Arkivoc 2017, 202. https://doi.org/10.24820/ark.5550190.p009.986 
32. Bodnár, B.; Mernyák, E.; Wölfling, J.; Schneider, G.; Herman, B. E.; Szécsi, M.; Sinka, I.; Zupkó, I.; Kupihár, Z.; Kovács, L. Molecules 2016, 21, 1212.

https://doi.org/10.3390/molecules21091212

33. Osatia, S.; Alia, H.; Guerina, B.; van Liera, J. E. Steroids 2017, 123, 27.

https://doi.org/10.1016/i.steroids.2017.04.007

34. Yuan, J. W.; Qu, L. B. Z. Naturforsch. 2017, 72(10), 717.

https://doi.org/10.1515/znb-2017-0074

35. Zhang, Z.; Zou, Y.; Deng, C. RSC Adv. 2017, 7, 14742.

https://doi.org/10.1039/C7RA01620D

36. Lau, Y. H.; Rutledge, P. J.; Watkinson, M.; Todd, M. H. Chem. Soc. Rev. 2011, 40, 2848.

https://doi.org/10.1039/COCS00143K

37. Hu, J.; Lu, J. R.; Ju, Y. Chem. Asian J. 2011, 6, 2636.

https://doi.org/10.1002/asia.201100378

38. J. Wu, Y. Gao, J. Lu, J. Hu and Y. Ju. Sens. Actuators 2015, 206, 516.

https://doi.org/10.1016/j.snb.2014.09.097

39. Y. M. Zhang, Y. Chen, Z. Q. Li, N. Li and Y. Liu. Bioorg. Med. Chem. 2010, 18, 1415.

https://doi.org/10.1016/i.bmc.2010.01.024

40. Bautista-Hernandez, C. I.; Negron-Silva, G. E.; Santillan, R.; Vergara-Arenas, B. I.; Angeles-Beltran, D.; Lomas-Romero, L.; Perez-Martínez, D. Tetrahedron 2018, 74, 2009.

https://doi.org/10.1016/j.tet.2018.03.008

41. Tankam, P. F. ; Mischnick, P.; Hopf, H.; Jones, P. G. Carbohydr. Res. 2007, 342, 2031.

https://doi.org/10.1016/i.carres.2007.05.007

42. Rensen, P. C. N.; van Leeuwen S. H., Sliedregt, L. A. J. M; van Berkel, T. J. C.; Biessen, E. A. L. J. Med. Chem. 2004, 47, 5798.

https://doi.org/10.1021/jm049481d

43. Mangunuru, H. P. R.; Yerabolu, J. R.; Liu, D.; Wang, G. Tetrahedron Lett. 2015, 56, 82.

https://doi.org/10.1016/j.tetlet.2014.11.013

44. Zhao, J. W.; Guo, J. W.; Huang, M. J.; You, Y. Z.; Wu, Z. H.; Liu, H. M.; Huang, L. H. Steroids 2019, 150, 108431.

https://doi.org/10.1016/j.steroids.2019.108431

45. Kitteringham, E.; Andriollo, E.; Gandin, V.; Montagner, D.; Griffith, D. M. Inorg. Chim. Acta 2019, 495, 118944.

https://doi.org/10.1016/i.ica.2019.05.043

46. Wilson, J. J.; Lippard, S. J. Chem. Rev. 2014, 114, 4470.

https://doi.org/10.1021/cr4004314

47. Juárez-Chávez, L.; Pina-Canseco, S.; Soto-Castro, D.; Santillan, R.; Magaña Vergara, N. E.; Salazar-Schettinof, P. M.; Cabrera-Bravo, M.; Pérez-Campos, E. Bioorg. Chem. 2019, 86, 452.

https://doi.org/10.1016/j.bioorg.2019.01.056

48. Soto-Castro, D.; Magaña-Vergara, N. E.; Farfán, N.; Santillan, R. Tetrahedron Lett. 2014, 55, 1014. https://doi.org/10.1016/j.tetlet.2013.12.066.

49. Özdemir, Z.; Rybková, M.; Vlk, M.; Šaman, D.; Rárová, L.; Wimmer, Z. Molecules 2020, 25, 3546. https://doi.org/10.3390/molecules25153546

50. Altinkok, C.; Karabulut, H. R. F.; Tasdelen, M. A.; Acik, G. Materials Today Commun. 2020, 25, 101425. https://doi.org/10.1016/j.mtcomm.2020.101425 


\section{Authors' Biographies}

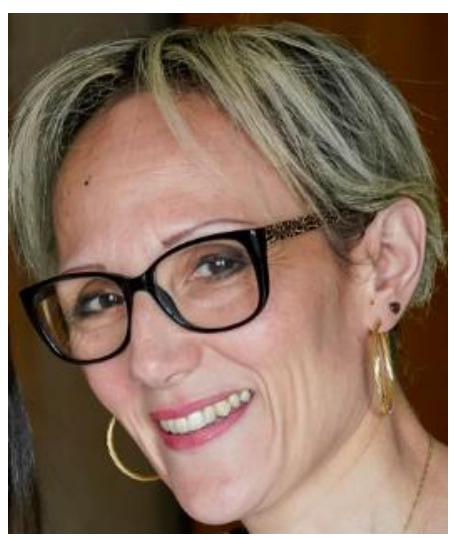

Malika Ibrahim-Ouali carried out her Ph.D. under the supervision of Professor Gramain in Clermont-Ferrand (France) in 1996. The work was focused on the synthesis of alkaloids. She was a postdoctoral fellow with Prof. Knochel (Humboldt fellowship) in 1996 in Germany where she got her first training in organometallic chemistry. In 1997, she joined Professor H. P Husson's group at the ICSN (Paris) as a postdoctoral researcher. Since 1998, she is an assistant professor at Aix-Marseille University and her field of interest remains the total synthesis of natural products.

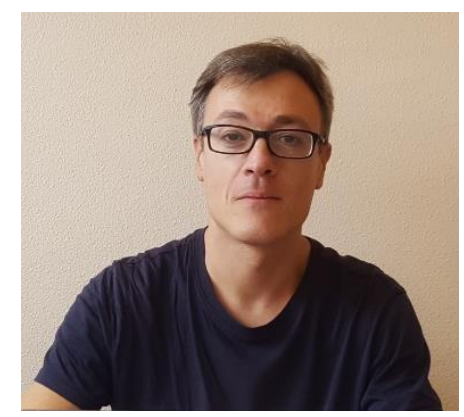

Frédéric Dumur received his Ph.D. in chemistry in 2002 from the University of Angers (France) under the supervision of Professor Pietrick Hudhomme. After Post-Doctoral studies at the University of Groningen (The Netherlands), Reims Champagne-Ardennes (France) and Versailles Saint-Quentin-en-Yvelines (France), he joined the Faculty of Sciences at Aix-Marseille University in 2008, where he is currently working as an Associate Professor. His research interests include the synthesis of phosphorescent dopants for OLEDs and photoinitiators of polymerization. He co-authored about 300 publications and 5 book chapters. 